\title{
Making of Alginate Dental Impression Material from Sargassum duplicatum
}

\author{
Ellya Sinurat $^{1 *}$, Subaryono ${ }^{1}$ and Anantaria Okawati Rambe ${ }^{2}$ \\ ${ }^{1}$ Balai Besar Riset Pengolahan Produk dan Bioteknologi Kelautan dan Perikanan, \\ K.S. Tubun, Jakarta 10260, Indonesia \\ ${ }^{2}$ Department of Dental Materials, Faculty of Dentistry, Universitas Indonesia, Jakarta \\ 10430,Indonesia
}

\begin{abstract}
This study was aimed to prepare dental impression material from Sargassum duplicatum taken from Binuangeun, Banten. The setting time was tested according to ANSI/ADA Specification for Alginate Impression Materials 1983. After extraction, obtained the alginate powder then mixed its water/powder ratio from the combination of alginate composition and tested final setting time. Variations of the formulations used different calcium sulfate $(0,1 \mathrm{~g} ; 0,2 \mathrm{~g}$; and $0,3 \mathrm{~g})$. Product quality parameters are lumps, solubility, consistency, flow, tearing, setting time. The alginate yield obtained from Sargassum duplicatum by $31 \%$ with characteristic gel strength by $816\left(\mathrm{gr} / \mathrm{cm}^{2}\right)$; viscosity $238 \mathrm{mPas}$ (2\%; room temperature). The highest ratio is the best ratio by adding calcium sulfate powder of 0.1 gram with a setting time of 3 minutes.
\end{abstract}

\section{Introduction}

Since 1940, alginate dental impression materials has been introduced [1]. Since then they have been used extensively in ddentistry as one of the group of so-called 'elastic' impression materials [2]. Alginate impression material is one of the most widely used impression materials in the field of dentistry because it is easy to use, economical, and provides good impression results. Another reason of using alginate include the low cost, a better tolerability on the part of the patient, the ease of manipulation, the short time needed for execution [3][4]. In Indonesia, dental alginate impression materials are widely used because the price is quite affordable and the printouts are quite accurate. However, the type of alginate impression material is still imported from abroad so the availability of this material is very dependent on the importer. Alginate impression materials are generally available in powder form containing a number of compositions, including sodium alginate, calcium sulfate, sodium phosphate, diatomic soil, and other substances [5]. The powder is then mixed with water and produces a mixture that is used to print mouth tissue. One of its main compositions, sodium

*Corresponding author : ellya_sinurat@yahoo.com 
alginate which is a sodium salt contained in alginic acid, can be obtained from the extraction of brown seaweed [6]. In this regard, it is necessary to carry out preliminary research to make alginate impression material that commonly found in Indonesian waters. In this study, various compositions used will be reviewed against the hardening time and the ratio of powdered water according to ANSI / ADA No. Specifications. 18: 1983 for dental alginate impression materials [7]. Potassium salt and sodium salt from alginic acid have properties that make alginate can be used as a dental impression material. Alginic acid, which is made from marine plants, is a high molecular weight block copolymer of anhydro- $\beta$-D-manuronic acid and anhydro- $\beta$-D-guluronic acid. The nature of the alginate raw material mainly depends on the degree of polymerization and the ratio of guluronate and mannuronate blocks in polymer molecules.

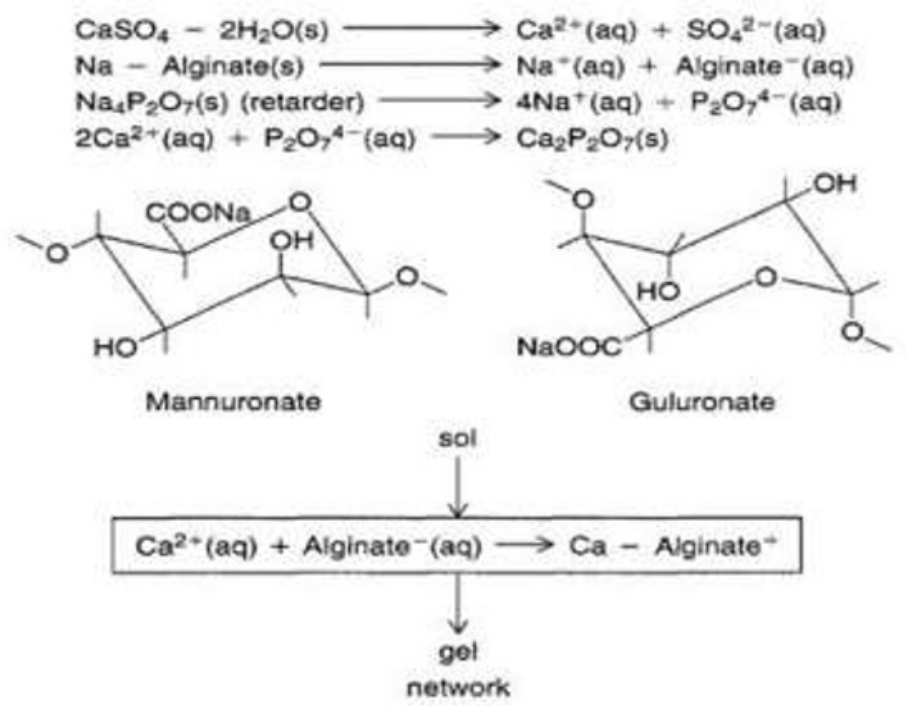

Fig. 1. Structure calcium alginate [2]

The manuronate area is stretchy and flat, while the guluronate region has low flexibility. In addition, generally guluronate blocks bind to $\mathrm{Ca}+2$. Therefore, alginate which is rich in guluronate forms a strong and brittle gel, while that rich in mannuronate form gels that are weaker and more form a weak and more elastic gel [2]. The ability of alginates to form gels is mainly related to the proportion of L-guluronate blocks. The chemical structure of alginate can be seen in Figure 1[2]. In a mixture of alginate printing materials, the powder contains calcium sulfate dihydrate, soluble alginate, and sodium phosphate. Calcium ions from calcium sulfate dihydrate react with phosphate ions from sodium phosphate and phosphophosphate to form insoluble calcium phosphate. Calcium phosphate will be more formed than calcium alginate because it has a lower solubility, so sodium phosphate is called a retarder because it provides working time for alginate mixtures [8]. The aim of research was study the ratio of water with alginate powder and calcium sulfate toward setting time. 


\section{Materials and methods}

\subsection{Materials}

Alginate powder from seaweed extract obtained from Sargassum duplicatum, Binuangeun, Banten.

\subsection{Extraction of alginate}

To obtain alginate powder, dried seaweed was soaked in $1 \% \mathrm{HCl}(1: 30 \mathrm{~b} / \mathrm{v})$ and extracted with $2 \% \mathrm{Na}_{2} \mathrm{CO}_{3}(1: 30)$ at $60-70{ }^{\circ} \mathrm{C}$ for $60 \mathrm{~min}$. Next, the seaweed ground and re-extracting at $60-70{ }^{\circ} \mathrm{C}$ for $60 \mathrm{~min}$, followed by filtering and then added with $\mathrm{NaOCl}(0.25 \%$ of the filtrate volume) for $30 \mathrm{~min}$. Then $10 \% \mathrm{HCl}$ was added to reach a $\mathrm{pH}$ of $2.8-3.2$ to separate alginic acid from filtrate, followed by washing the alginic acid until neutral. After that, the conversion to sodium alginate was performed by adding $10 \% \mathrm{NaOH}$ to $\mathrm{pH} 7-8$, followed by separating sodium alginate in IPA (1:2 v/v), and-stirring, and leaving for $30 \mathrm{~min}$. Finally, the product was dried in the sun and grinded to obtained sodium alginate powder [9]. The characterization of alginate (yield, gel strength, viscosity, moisture content, $\mathrm{pH}$ ) and as comparison used alginate commercial; making experimental alginate impression materials with various calcium sulfate compositions over time of setting.

\subsection{Making the alginate impression material based on setting time}

The first, sodium alginate and different water quantities $(20-27 \mathrm{~mL})$ are mixed interval $1 \mathrm{~mL}$. The preparation of an alginate impression material with powder composition I intended to attain the best ratio of the sodium alginate powder mixture with water. After that mixed alginate powder, sodium phosphate with varians calcium sulfate $(0,1 \mathrm{~g} ; 0,2 \mathrm{~g}$ and $0,3 \mathrm{~g})$ were mixed with water. Finally, the setting time of the powder composition was recorded. The criteria assessment include: lump, dissolved, stirring, torn, flow, elastic, and setting time.

\section{Results and discussion}

\subsection{Characterization of alginate powder}

The results of the quality of alginate flour from extraction of Sargassum duplicatum seaweed obtained as shown in Table 1 . Based on the results of the analysis, the alginate from S. duplicatum have higher viscosity and gel strength compared to commercial alginates. High viscosity and gel strength were indicated that this alginate contain high glucuronate content compared to manuronates. This is because guluronate compounds more easily interact with cations that have a valence of 2 , thus increasing gel strength and viscosity [2]. Conversely, the higher mannuronic acid produces a weaker and more elastic gel, with better freeze-thaw stability behavior [3] [5]. For dental impression materials, it is expected that alginate was easily binding with calcium and has a good elasticity (based on the requirements according to ANSI/ADA Specification for Alginate Impression Materials no. 18: 1983). 
Table 1. Characteristic of alginate powder

\begin{tabular}{|c|c|c|}
\hline \multirow{2}{*}{ Parameters } & \multicolumn{2}{|c|}{ Result of analysis } \\
\hline & $\begin{array}{c}\text { Alginate from Sargassum } \\
\text { duplicatum }\end{array}$ & $\begin{array}{r}\text { Standard alginate } \\
\text { (Sigma A2158) }\end{array}$ \\
\hline Yield (\%) & 31 & - \\
\hline Colour powder (visual) & Light brown & beige \\
\hline Moisture content (\%) & 16.95 & 12.4 \\
\hline Whiteness degree (\%) & 44.1 & - \\
\hline $\begin{array}{l}\text { Viscosity at room temperature } \\
(2,0 \%) \text { in mPas }\end{array}$ & 238 & 105 \\
\hline Viscosity at $75^{\circ} \mathrm{C}(2,0 \%)$ in $\mathrm{mPas}$ & 84 & 40 \\
\hline $\begin{array}{l}\text { Gel strength }(1.5 \%)+\mathrm{CaCO}_{3} 20 \\
\mathrm{mM} ; \text { GDL } 30 \mathrm{mM} \text { after } 2 \text { hours } \\
\left(\mathrm{g} / \mathrm{cm}^{2}\right)\end{array}$ & 816 & 420 \\
\hline
\end{tabular}

\subsection{Making of alginate dental impression material}

From the results of mixing water as much as $20 \mathrm{ml} ; 21 \mathrm{ml} ; 22 \mathrm{ml} ; 23 \mathrm{ml} ; 24 \mathrm{ml} ; 25 \mathrm{ml} ; 26$ $\mathrm{ml} ; 27 \mathrm{ml}$, with the same amount of sodium alginate powder as 5 grams, the following results are presented in Table 2. From this studied the best ratio of water and sodium is $24 \mathrm{~mL} / 5$ grams alginate. The use of more than $24 \mathrm{ml}$ of water produces a consistency of the mixture that is non-creamy because it is increasingly runny, and the mixture no harden.

Table 2. Results of making the alginate impression material with different alginate ratio

\begin{tabular}{|l|c|c|c|c|c|c|c|c|}
\hline \multirow{3}{*}{ Criteria } & \multicolumn{7}{|c|}{ Water alginate ratio } \\
\cline { 2 - 10 } & $\begin{array}{c}20 \mathrm{~mL} / \\
5 \mathrm{~g} \\
\text { Sodium } \\
\text { alginate }\end{array}$ & $\begin{array}{c}21 \mathrm{~mL} / \\
5 \mathrm{~g} \\
\text { Sodium } \\
\text { alginate }\end{array}$ & $\begin{array}{c}22 \mathrm{~mL} / \\
5 \mathrm{~g} \\
\text { Sodium } \\
\text { alginate }\end{array}$ & $\begin{array}{c}23 \mathrm{~mL} / \\
5 \mathrm{~g} \\
\text { Sodium } \\
\text { alginate }\end{array}$ & $\begin{array}{c}24 \mathrm{~mL} / \\
5 \mathrm{~g} \\
\text { Sodium } \\
\text { alginate }\end{array}$ & $\begin{array}{c}25 \mathrm{~mL} / \\
5 \mathrm{~g} \\
\text { Sodium } \\
\text { alginate }\end{array}$ & $\begin{array}{c}26 \mathrm{~mL} / \\
5 \mathrm{~g} \text { Sodium } \\
\text { alginate }\end{array}$ & $\begin{array}{c}27 \mathrm{~mL} / 5 \\
\text { g Sodium } \\
\text { alginate }\end{array}$ \\
\hline Lump & yes & Yes & Yes & Yes & No & No & No & No \\
\hline Dissolved & yes & Yes & Yes & Yes & yes & Yes & Yes & Yes \\
\hline Stirring & Hard & Hard & Hard & Easy & Easy & Easy & Easy & Easy \\
\hline Consistency & creamy & Creamy & creamy & creamy & Creamy & $\begin{array}{c}\text { Non } \\
\text { creamy }\end{array}$ & $\begin{array}{c}\text { Non } \\
\text { creamy }\end{array}$ & $\begin{array}{c}\text { Non } \\
\text { Creamy }\end{array}$ \\
\hline Torn & Bad & Bad & Good & Good & Good & Good & Good & Good \\
\hline Elasticity & Elastic & Elastic & Elastic & Elastic & Elastic & Elastic & No elastic & No elastic \\
\hline Setting time & 1 min & 1 min & 2 min & 2 min & 3 min & 3 min & No hard & No hard \\
\hline
\end{tabular}


Furthermore, the formulation of making alginate impression material with a variety of calcium sulfate was conducted. The mixing results obtained as shown in Table 3 . The addition of calcium sulfate that meets the standards according to ANSI / ADA Specification for Alginate Impression Materials no. 18: 1983 based on setting time is 0.1 gr with a 3 minutes setting time.

Table 3. Characteristic of alginate impression material at different calcium sulfate

\begin{tabular}{|l|l|l|l|}
\hline Criteria & $\begin{array}{l}24 \mathrm{~mL} \mathrm{H}_{2} \mathrm{O} / 5 \mathrm{~g} \\
\text { Sodium alginate }+0,1 \\
\mathrm{gr} \mathrm{CaSO}_{4}\end{array}$ & $\begin{array}{l}24 \mathrm{~mL} \mathrm{H}_{2} \mathrm{O} / 5 \mathrm{~g} \\
\text { Sodium alginate }+0,2 \\
\text { gr CaSO }\end{array}$ & $\begin{array}{l}24 \mathrm{~mL} \mathrm{H}_{2} \mathrm{O} / 5 \mathrm{~g} \\
\text { Sodium alginate }+0,3 \\
\mathrm{gr} \mathrm{CaSO}_{4}\end{array}$ \\
\hline Lump & No & No & No \\
\hline Dissolved & yes & Yes & Yes \\
\hline Stirring & Easy & Easy & Easy \\
\hline Consistency & creamy & Creamy & Non creamy \\
\hline Flow & Good & Good & Good \\
\hline Torn & No & No & No \\
\hline Elasticity & Elastic & Elastic & Elastic \\
\hline Setting time & 3 min & 3 min & 5 min \\
\hline
\end{tabular}

However, the obtained results inversely correlated with the theory because the addition of a higher amount of sodium phosphate powder shortened the setting time. The combination of calcium salt and sodium alginate with water produces a water-insoluble elastic gel known as calcium alginate [11]. The chemical reaction is as follows [7]:

$$
\mathrm{Na}_{2} \mathrm{Ag}+\mathrm{nCaSO}_{4} \quad \longrightarrow \quad \mathrm{Ca}_{\mathrm{n}} \mathrm{Ag}+\mathrm{nNa}_{2} \mathrm{SO}_{4}
$$

Sodium alginate calcium sulfate calcium alginate sodium sulfate

Addition of calcium sulfate to alginate forms a calcium alginate compound and is a byproduct of sodium sulfate. Calcium alginate has soft gel properties, water insoluble, and gelatinous. The results of the reactions can be seen in Figure 2.

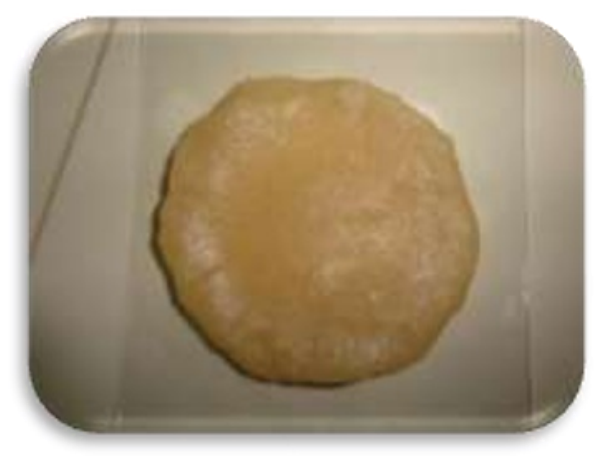

Fig. 2. Mixed alginate and calcium sulfate

To obtain a better time setting than commercial standards it is necessary to add other ingredients like titanium fluoride as acceleration reaction. Several materials were potassium sulfate can using to produce smooth surface quality, $\mathrm{MgO}$ to higher tear energies, pigment, flavor as like as product of alginate dental impression commercial [9]. Impression materials 
must have ability to reproduce a true measured value and they should be dimensionally stable across time [16]. By this research given information that Sargassum duplicatum potential has potential to be further develoved dental alginate imppression material product orginal from Indonesia.

\section{Conclusion}

Based on the findings of this study, the best ratio of water with alginate powder by adding calcium sulfate powder of 0.1 gram with a setting time of 3 minutes. The overall results obtained by the formula of dental alginate molds consisting of a water ratio of $24 \mathrm{~mL}, 5 \mathrm{~g}$ sodium alginate and $0.1 \mathrm{~g}$ of calcium sulfate, obtained a time setting of 3 minutes.

\section{References}

1. Amalgamated Dental Company. Improvements in or relating to materials for taking impressions for dental or other purposes. British patent,518,596;194

2. C. Robert, JM Powers. Restorative Dental Materials. 11ed. St.Louis: Mosby (2002).

3. R.W. Philips. Science of Dental Materials. 11 ed. St. Louis : Elsevier. (2003).

4. G. Cervano, L. Fiorillo, A. S. Herford, L. Laino, G. Troiano, G. Amoroso, S. Crimi, M. Matarese, Cesare D’Amico, E. N. Siniscalchi and M. Cicciù. Mar. Drugs, 17 1, 18. (2019)

5. Nandini, Vidyashree. J Conserv.Dent (2008)

6. Agriculture and consumer protection FAO Corporate Document Repository, (1995)

7. E.W Skinner, R.W. Phillips, The Science of Dental Materials. 8ed. Philadephia : Saunders (1982)

8. P. Mary, W.J Burckhard, D. A. Mitts, and K. B. Williams, 80, 6 :1110-1115. (2010)

9. N. Nallamuthu, M. Braden, M. P.Patel. Dental materials 28; 756-762 (2012)

10. M. Murdinah, E Sinurat. Penelitian Diversifikasi Produk Berbasis Rumput Laut Coklat Sebagai Bahan Pangan Fungsional, Farmasi dan Antivirus White Spot pada Udang. (Jakarta: Balai Besar Pengolahan Produk dan Bioteknologi Kelautan dan Perikanan). (2006)

11. E Sinurat dan R. Marliani. JPHPI 2017, 20, 2 p: 351-361. (2017)

12. K.I., Draget, O., Gaserod, I. Andersen, B., Storbakken, B.T., Stokke, and O. Smidsod,.Effect of molecular weight and elstic segment flexibility on syneresis in Caalginate gels. Food Hydrocolloids 15: 485-490. (2001)

13. ANSI/ADA Specification No. $18: 1983$.

14. R.W. Phillips. Science of Dental Materials. 11 ed. St. Louis : Elsevier. 2003.

15. CP Reis, RJ. Neufeld, S.VilelaA >J Ribeiro, F.Veiga. Review and current status of emulsion/dispersion technology using internal gelation process of the design of alginate particles. Journal of Microencapsulation. 23: (3) 245-257. (2006)

16. Manisha M.K and Thomabre R.U. J.Clin Diagn Res. 9, 8: ZC98-ZC102 (2015). 